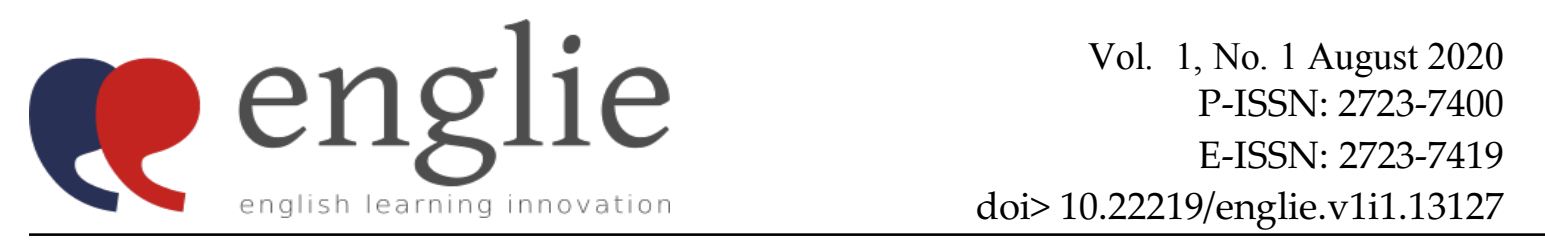

\title{
The Use of Picture Cards as Teaching Media to Improve Speaking Ability of Eleventh Graders: A Classroom Action Research
}

\author{
Rizki Ambarwati \\ Global Language Academy, Bali, Indonesia \\ Corresponding Author: rizkiambarwati21@gmail.com \\ Nur Hayati \\ English Department, Universitas Negeri Malang, Malang, Indonesia
}

\begin{abstract}
English has been well-known as the global language since the last three decades. English is not only as a mean of international communication but as a tool to gain and exchange information as well. Therefore, English becomes the language taught the most in school. Learning language cannot be separated from language skills. Mastering 4 skills of language is important to be acknowledge as Language master. However, many students have difficulties in mastering the language skills, speaking especially. This condition may occur because of different reasons. The result of preliminary study showed that the students of XI MIPA 5 at SMA Negeri 4 Malang had lower score in speaking compared to other language skills. It was because they got difficulty in developing idea of what to say which then made them having no confidence in speaking. Moreover, they were also afraid of making mistake. Therefore, this Action Research was employed as the research design to improve the students' ability in speaking. The subjects of this study were students of XI MIPA 5 science class which consists of 33 students. The research findings showed that the use of picture cards has progressively improved the students' speaking ability proven by the improvement of their speaking score. There were $87.87 \%$ students could improve their score by at least 5 points. Using picture cards as teaching media helped the students to have a betterment of speaking skill. The result of the observation checklist and field note showed that using picture cards media in teaching cause and effect made students easier in understanding the material which then it helps them easier in doing the speaking performance.
\end{abstract}

Keywords: picture cards; speaking, classroom action research

\section{INTRODUCTION}

English has been well-known as the global language since the last three decades. English plays an important role as a mean of international communication, a tool to gain and exchange information. Thus, learning English is significant. Crystal (2003) stated that in more than 100 countries around the world the language taught the most in school is English. This proves the importance of learning English for people and it proves that English is acknowledged as global language. 
Learning a language cannot be separated from language skills such as listening, reading, writing, and speaking. We need to master all skills to be acknowledge as English master. In educational field, speaking is seen as the most important skill among all skills. Aleksandrzak (2011) stated that "speaking is perceived as the most fundamental skill to acquire". It is because, being able to speak English fluently is the ultimate goal and the focus for both teachers and students in learning a language. Speaking skill is being considered as difficult skill by the students because of its highly complex activities. To be able to speak fluently, at least students need to have enough range of vocabularies, understand the basic grammar, have a good pronunciation and know the use of English in a real context. In fact, the things mentioned seem to be problems that students may encounter.

Another the reasons of students' difficulty in speaking English are teacher's teaching method, large number of students in the class, lack motivation of the students, limited school hours, students' attitude, shyness and interest, students' cultural factors, family and society (Herminingsih, 2010). Additionally, according to Bashir, Azzem \& Dogar (2011) many students tend to be shy and unmotivated to speak English in front of the class. While some others are afraid of making mistakes and they don't have any idea to be developed or they don't know what to say more. The factors mentioned above hinder the students from having positive improvement in their speaking skill.

Similar problems also occurred in SMAN 4 Malang. It was found out that most of students had difficulty in speaking that resulted in their lower score for speaking compared to other skills. The lack of vocabularies, not having a good understanding of English grammar, and also not having ideas of what to say became the main reasons of students' difficulty in speaking. The researcher realized that the teacher rarely used suitable teaching media that can help and stimulated the students speak more confidently and fluently. In accordance with the problems, students can learn best if the teaching and learning process involves and stimulates them physically, emotionally, and cognitively. Therefore, creating such an interesting activity in teaching and learning process is essential for teacher to trigger students' interest, motivate students as well as encourage them to speak more.

Selecting wisely an appropriate media for the topic and the students' need to improve their speaking skill is also crucial. The learning objective will be hard to achieve without using the appropriate media to support the learning. In another word, media holds an important role in teaching and learning process. Thus, the researcher decides to use cards as a teaching media that can be used to help the students improving their speaking skill. Previous research conducted by Solichah (2016) proved that using topic-based picture cards resulting in the improvement of students' speaking score. The result showed that for about $80 \%$ of the students got score more than 80 which was considered as good level and the result of questionnaire showed that $91 \%$ of students enjoyed the use of picture cards as the teaching and learning media. Therefore, based on the problems found by the researcher, also because not many of the previous studies have dealt with the use of picture cards on cause and effect relationship. Therefore, in this study, the researcher decided to conduct 
an action research on using of picture cards as teaching media to improve the ability of the eleventh graders in speaking.

\section{METHOD}

In this study, Classroom Action Research (CAR) proposed by Kemmis \& McTaggart is implemented. Classroom Action Research as defined by Latief (2010), is an effective way to improve both the English teachers' quality in terms of performance and the achievement of the students in learning English. and it is a kind of research resulting in variations of strategies to teach English. By implementing Classroom Action Research, it is expected that it can help the students to solve their problem in learning English. According to Kemmis \& McTaggert (1998), Action Research involves cycles which consists of 4 stages: Planning, Acting, Observing, and Reflecting. Kemmis \& McTaggert stated that the result of one cycle determines the following cycle's need. At the Plan stage, the researcher focuses on what will be the most appropriate media in addressing the problems. Then, the Act stage where the already planned teaching media will be used is conducted. During the implementation, the researcher and the observer observe the Act and collect all the data. Then the Reflection stage is done to know whether or not the results meets the criteria of success. Those stages belong to one cycle. When the result doesn't reach the criteria of success, then the next cycle covering the same four stages needs to be conducted. The cycle will be stopped if the result of implementing the Action Research reaches the criteria of success determined by the researcher.

\section{FINDINGS AND DISCUSSION}

The result of the students' speaking performance shows improvement after the action research implementation. The students' average score before the implementation was 84.67. Meanwhile, after the implementation, the average score of the students became 87 . There were 29 students who were able to improve at least 5 point from their previous point. 7 of them even got higher than 5 point they should improve. There were only 4 students who improved their score less than 5 points from their previous score. In other words, $87.87 \%$ of the total students could reach the criteria of success and $12.12 \%$ of the students could not reach it. It means the criteria of success determined by the researcher were successfully achieved. 
Figure 1. Students' Average Speaking Score

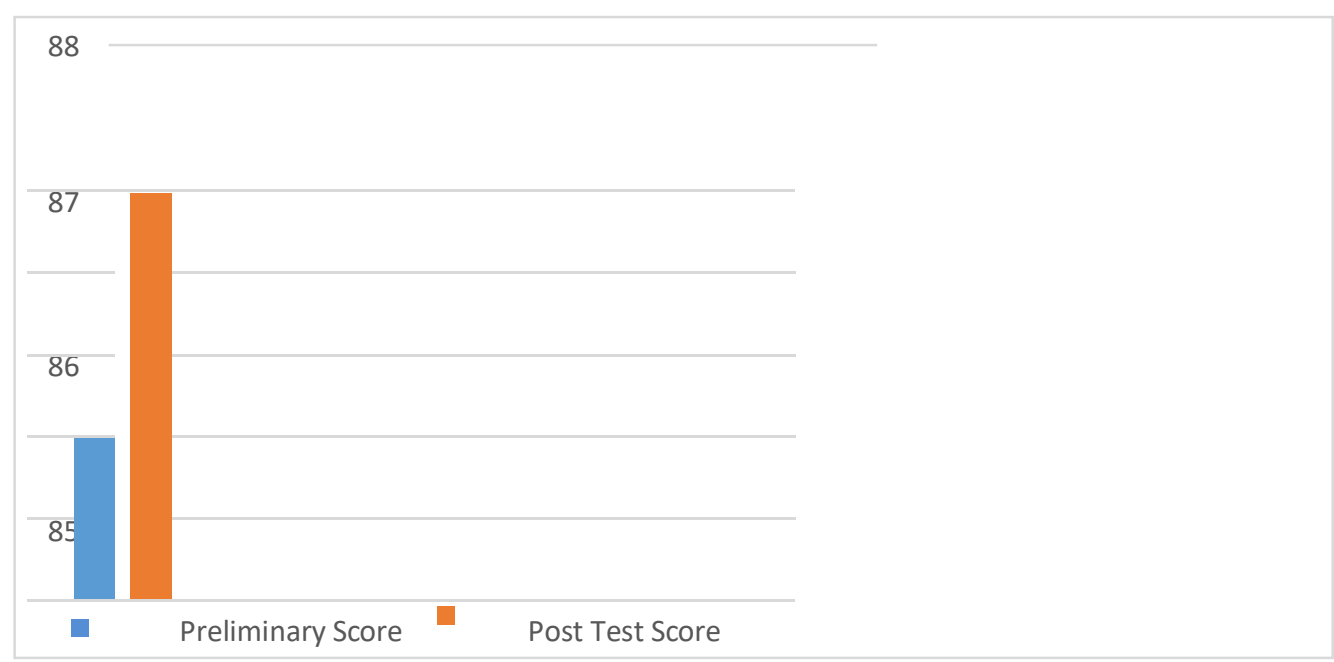

Figure 2. Comparison on Speaking Aspects from Students' Speaking Score

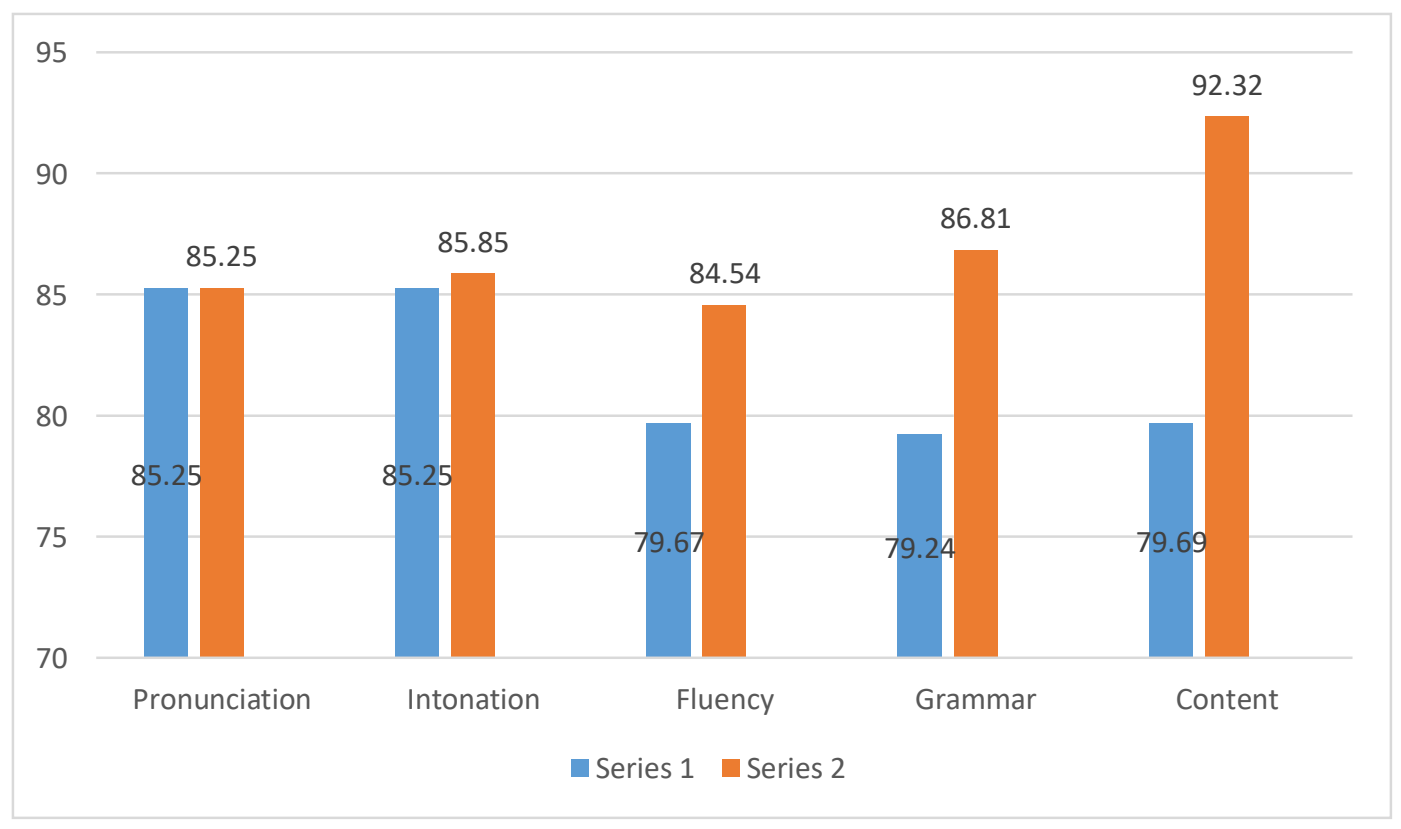

Based on the chart, it can be seen that almost in each aspect of speaking score showing an improvement, except for pronunciation aspect. In Intonation aspect, the average of students' score before the implementation was $85.25 \%$ and after the implementation it became $85.85 \%$. There was an improvement even it was not significant. For the aspect of Fluency, the average of score in preliminary showed it was only $79.67 \%$, while $84.54 \%$ was the average of fluency score after the implementation. The average score for grammar aspect was $79.69 \%$ before the implementation and it became $86.81 \%$. While for aspect of Content showed the most significance improvement, which is from $79.69 \%$ becoming $92.32 \%$.It can be concluded that the implementation of picture cards media have impact on improving the students' speaking score, and based on the data analysis, the most significance improvement of score was on content aspect. It means that 
the use of picture cards as teaching media significantly help students elaborating and developing the idea of what to say in speaking performance.

At the first meeting of implemented strategy, as stated in field notes and observation checklist, the students were enthusiast in doing the activities. This means that the use of picture media collaborated with the teaching technique could encourage the students' motivation and interest in doing the teaching and learning. They also had fun in doing the task. The media and activities attracted the students' attention, they had more focus in doing the teaching and learning. Most of the students in group were actively doing their job as it was being divided already by the captain of the group. They also discussed to finish the task together. However, there were still a few students who were not active in doing group task. The students also had many mistakes in constructing cause-effect sentences based on the game activity. Based on the observation checklist and field note, it was known also that the students were not really playing the game as its rules. It seems like it was because the rules were not stated clearly and the students didn't really pay attention to the rules when it was explained. However, the activity and game still run well.

In the second meeting, the students' participation got better than the first meeting. Based on the field note and observation check list, the students already had better understanding about the concept and how to use picture cards as media in learning cause and effect. The students were actively involved in the group work discussion and they also actively answered the teacher questions related to the material. In this meeting, the researcher noticed that the students didn't make mistakes in constructing the cause and effect sentences as much as they did in the previous meeting. But they still didn't play the game as its rules. However, the game run well. The students also enjoyed the game activity and the role play.

In the last meeting of the implementation, students were given an exercise just to make sure that they had already understood the material. Then they were given a picture card to be developed as dialog which then they performed it in front of the class. The researcher noted that the students didn't have any difficulty in developing a dialog about cause and effect and developing the dialog. The content of dialog also showed that they constructed more cause and effect sentences. They also had fun in writing the dialog with their group. They seemed enjoying their performance since they looked more comfortable in doing that.

\section{DISCUSSION}

In assessing the speaking performance of the students, the scoring rubric was used by the researcher. The researcher adjusted the scoring rubric based on the students' level and the learning material. There are 5 aspects in speaking scoring rubric. Each of aspect has different weighing. The scores from each aspect then were being added to get the total score.

In the implementation, the researcher combined the media with the game. According to Khan (as cited by Suyanto, 2007), to stimulate students' mindset in learning a language, 
we can implement game in the learning. In this research, the game was done in groups. It was aimed to ease the students to do the task, besides that the learning would be more interesting if the students competed with other students. The researcher grouped the students to help them making cause and effect sentences based on the media. The group consisted of 3-4 students. At the end of the study, the researcher gave the students feedback related to what they had just did. The researcher also discussed about the mistakes that the students made such as they used double connective words in one sentence and some used incorrect connective word to show cause and effect sentences. This was purposed to hinder the students to make such mistakes in the next meeting.

In implementing the strategy, the researcher used picture cards as the teaching media. Picture cards were used to help the students in constructing the idea. It made the students easier in developing the dialog for speaking. The use of picture cards also was aimed to make students to be more creative and this convince the researcher that using picture cards as teaching media can really help the students to improve the ability of XI MIPA 5 students at SMA N 4 Malang in speaking English.

The result of post-test done at the end of the cycle 1 proved that the students' speaking ability showing an improvement compared to before the implementation of the cycle. This showed that using picture cards as teaching media successfully improved the students' speaking ability. Picture cards could help the students in elaborating idea based on the topic. The students could tell more than 3 cause and effect sentences in their dialog using the picture cards. Furthermore, Susanto (2011) added that students could understand the topic better by using picture cards. Moreover, picture cards could stimulate the idea of topic so that the students could develop more ideas or story for their speaking performance.

Students' participation also becomes one of the data in this research. The researcher gathered the data about students' participation through observation checklist and field note. The researcher also did preliminary study. Based on that, the researcher noticed that the teacher used various kinds of teaching techniques and method but the teacher rarely used media in teaching speaking. According to Suyanto (2007: 101), the importance of the use of media in teaching and learning process is that the use of media help both of teacher and students to increase the teaching and learning quality, especially English in this context. Additionally, Naz and Akbar (2008) stated that "Media are the means for transmitting or delivering messages and in teaching-learning perspective delivering content to the learners, to achieve effective instruction". It means that, teaching media for learning is very crucial to help students to have a better understanding about the material.

The researcher noticed that before the implementation of this research, the students were having difficulty in performing speaking. It was because they were difficult to elaborate the idea, they did not know what to say whenever they were asked to perform speaking. Therefore, even though they had range of vocabulary, they could only speak for a little. For example, when they were asked to perform speaking in a group of 3-4 students, each of them tended to speak only 3-4 sentences and those included "yes, no, hi". However, after the researcher implemented picture cards as media in teaching speaking, 
their performance changed. Students could produce more sentences. They also seemed to enjoy the activity. They seemed to be more confidence as well.

\section{CONCLUSION}

Based on the result in findings of the study, it can be concluded that using picture cards media can improve the students' ability in speaking. The improvement is shown from the result of students' speaking score in the final test. However, the success of picture cards as media in teaching speaking cannot be separated from the teaching technique used to support the use of teaching media. The students' improvement in speaking also can be seen from the students' participation towards the implementation of picture cards as media. This teaching media can help students to improve their speaking ability as it helps them develop and elaborate the idea related to the topic. So that the students do not get stuck on what to say in speaking performance.

In addition, the participation of the students towards the implementation of picture cards were also positive. The students were focusing on the task during the learning process. They also look happy and they enjoyed the learning using the media.

Based on the result, it is suggested that the English teachers of SMA N 4 Malang will use the teaching media in teaching speaking. It is because picture cards as teaching media can be used as collaboration with teaching technique that can avoid the students from the boredom. This teaching media can also ease the students to elaborate idea so it helps the students to solve the speaking difficult.

The researcher also suggests to other English teacher in other schools to adapt this teaching media and the technique as it has been proven that students' speaking ability showing improvement after the implementation. This teaching media also can be implemented to teach other topic and it can be used to teach students at different levels as well. As for future researchers, this action research may become a reference in conducting similar study with different level of students, different material, and different skills as the focus of research. Even, it can be used to conduct the research with implementing different teaching technique or strategy.

\section{ACKNOWLEDGMENTS}

This report is a part of final project when the authors were studying at Universitas Negeri Malang for PPG (Pendidikan Profesi Guru) academic year 2018/2019, granted by Ministry of Education.

\section{REFEENCES}

Aleksandrzak, Magdalena. (2011) Problems and Challenges in Teaching and Learning Speaking at Advanced Level GGlottodidactica. An International Journal of Applied Linguistics. Vol.37

Bailey, K. M. (2005) Practical English Language Teaching: Speaking. New York: McGraw Hill.

Bashir, M. Azzem, M. \&Dogar, H.A. (2011) Factor Effecting Students' English Speaking Skill: British Journal of Art and Social Sciences. 
Crystal, D. (2000) English as a Global Language: Cambridge University Press.

Goodman, J. (2007) Picture Stories in the Communicate Classroom, (Online), (http://www.teachingenglish.org.uk/indeks.sthml), accessed on December 16th, 2014.

Herminingsih, I.M. (2010) Forms-focused and Meaning-focused Instructional Model to Promote Speaking Ability in an EFL Classroom. Malang: State University of Malang Press (Second Language Acquisition).

Kemmis, S and Mc Taggart. (1998) The Action Research Planner (3rd Edition). Gelong: Deakin University.

Kothari, C.R. (2004) Research Methodology: Methods and Techniques, Second Revised Edition. India: New Age International Publisher.

Latief, M.A. (2012) An Introduction Research methods on language learning: an introduction. Malang: Universitas Negeri Malang.

Naz, AhsanAhtar and Akbar, RafaqatAli. (2008) Use of Media for Effective Instruction its Importance: Some Consideration. Journal of Elementary Education Vol. $18(1-$ 2) $35-40$.

Solichah,. LutfiWafiru. (2016) Using topic-based picture cards to improve speaking skills of the eighth graders at SMPN 13 Malang. Malang: Universitas Negeri Malang.

Suyanto, K.K.E. (2007) English for Young Learners. Jakarta: Bumi Aksara.

Wahyunianto, Dian. (2012) Using Pictorial Cards to Enhance Speaking Skill of The Tenth Grade Students of SMAN 5 Kediri. Malang: Universitas Negeri Malang 